Proc. Estonian Acad. Sci. Geol., 2003, 52, 4, 213-238

\title{
Wenlock-Ludlow boundary beds and conodonts of Saaremaa Island, Estonia
}

\author{
Viive Viira and Rein Einasto \\ Institute of Geology at Tallinn Technical University, Estonia pst. 7, 10143 Tallinn, Estonia; \\ viira@gi.ee, einasto@gi.ee \\ Received 22 January 2003, in revised form 12 August 2003

\begin{abstract}
Conodonts of the genus Ctenognathodus form an important part of the fossil fauna through the Wenlock-Ludlow boundary beds on Saaremaa Island. In the collections from the Anikaitse, Hülge, and Soeginina cliffs of the uppermost Rootsiküla and lowermost Paadla stages three new species of Ctenognathodus are identified, together with two new species of Ozarkodina. One more new species, Ctenognathodus jeppssoni sp. nov., is described from the Sauvere Beds of the Paadla Stage. Conodont evidence suggests that the Soeginina Beds in the stratotype section are the lowest stratigraphic unit of the Paadla Stage and the Ludlow Series, as presumed earlier by cyclostratigraphic investigations. The layers of the Anikaitse cliff with unique conodont fauna are considered as an independent rock-unit - the Anikaitse Beds.
\end{abstract}

Key words: conodonts, taxonomy, biostratigraphy, cyclicity, Wenlock, Ludlow, Estonia.

\section{INTRODUCTION}

The boundary between the Wenlock and Ludlow in Estonia is usually fitted with the boundary of the Rootsiküla and Paadla regional stages (Nestor 1997), but exact dating is complicated because of the lack of graptolite records (Fig. 1). The lower boundary of the Paadla Regional Stage was originally established at the top of the Kaarma dolomite, known as good building material on Saaremaa Island (Luha 1930, 1933). However, the study of borehole sections after World War II revealed that it was a lithostratigraphic cycle boundary in the middle of the Paadla Stage (Aaloe 1963). Preliminary faunal and cyclostratigraphic data from borehole sections allowed more exact positioning of the boundary of the Rootsiküla and Paadla stages between the Soeginina and Sauvere beds (Einasto 1970; Klaamann 1970). New interest in this interval appeared in connection with the study of the Wenlock-Ludlow boundary in the Baltic Silurian (Einasto 1962, 1991, 1996; Nestor 1997; Nestor \& Einasto 1997; Kaljo et al. 1997, 1998) and fixation of a major gap at the boundary of the Rootsiküla and Paadla stages (Nestor \& 


\begin{tabular}{|l|l|l|}
\hline \multirow{3}{*}{$\begin{array}{l}\text { Ludlow } \\
\text { Lower part }\end{array}$} & Uduvere Beds \\
& \multirow{4}{*}{$\begin{array}{l}\text { Paadla Stage } \\
\text { Wenlock } \\
\text { Upper part }\end{array}$} & Sauvere Beds \\
& \multirow{3}{*}{ Rootsiküla Stage } & Soeginina Beds \\
\hline & & Anikaitse Beds \\
& & Vesiku Beds \\
& & Kuusnõmme Beds \\
\hline
\end{tabular}

Fig. 1. Stratigraphical scheme of Wenlock-Ludlow boundary beds.

Nestor 1991). That boundary is of a higher rank than usual mesocycle boundaries within the Jaagarahu, Rootsiküla, and Paadla stages. This is expressed in major faunal changes and extensive palaeogeographical distribution of the erosion surface at the boundary. The cyclostratigraphic correlation and indirect biostratigraphic data show that the gap at this boundary in central Saaremaa correlates with the top of the nilssoni Zone in the Central, Swedish-Latvian Confacies Belt. In the Ventspils borehole section, a $1 \mathrm{~m}$ interlayer of nodular limestone of open shelf origin occurs at this level between basinal graptolitic argillite and clayey marlstone of the slope facies (Gailite et al. 1987). It was just at this stratigraphic level (above the $N$. nilssoni graptolite Zone) that the replacement of graptolitic shale by pelagic Ockerkalk limestone took place in the oceanic area in Central Europe (Jaeger 1959, 1976). Therefore the Soeginina Beds can be considered as the basal part of the Ludlow (Einasto 1991). In the Soeginina Beds distinct transgressive features appear compared to the underlying Vesiku Beds: rich normal marine fauna (corals, nautiloids) and numerous bivalves, gastropods, and calcareous algae (Solenopora). Present conodont studies of the stratotype section of the Soeginina Beds on Saaremaa confirm that the conodont fauna contains species typical of the Paadla Stage and therefore the Soeginina Beds should belong to this stage (Fig. 1). The easternmost, Anikaitse cliff and Sakla borehole sections yield a specific conodont fauna corresponding to a gap on western Saaremaa.

In this paper the conodonts and cyclicity at the transition between the Rootsiküla and Paadla stages, that is, the Soeginina and Sauvere beds, are considered, based on the material from some outcrops of Saaremaa Island, Estonia (Fig. 2). The study was initiated by the discovery of unique conodonts from the Anikaitse and Hülge cliffs on easternmost Saaremaa and Soeginina cliff on westernmost Saaremaa, and some localities on central Saaremaa. For correlation and investigation of morphologic changes of conodont elements, data from some additional outcrops and borehole sections were used. An important aim was to establish a formal status for Ctenognathodus jeppssoni sp. nov., the species described first by L. Jeppsson as Ligonodina confluens $n$. ssp. 1 in his paper of 1972 and mentioned later by Strömberg (1997) as Ctenognathodus n. sp. L. The specimens figured here are deposited in the Institute of Geology at Tallinn Technical University under the the collection number 371. In the description of conodonts, the new anatomical notation of elements is used, proposed by Purnell et al. (2000). 


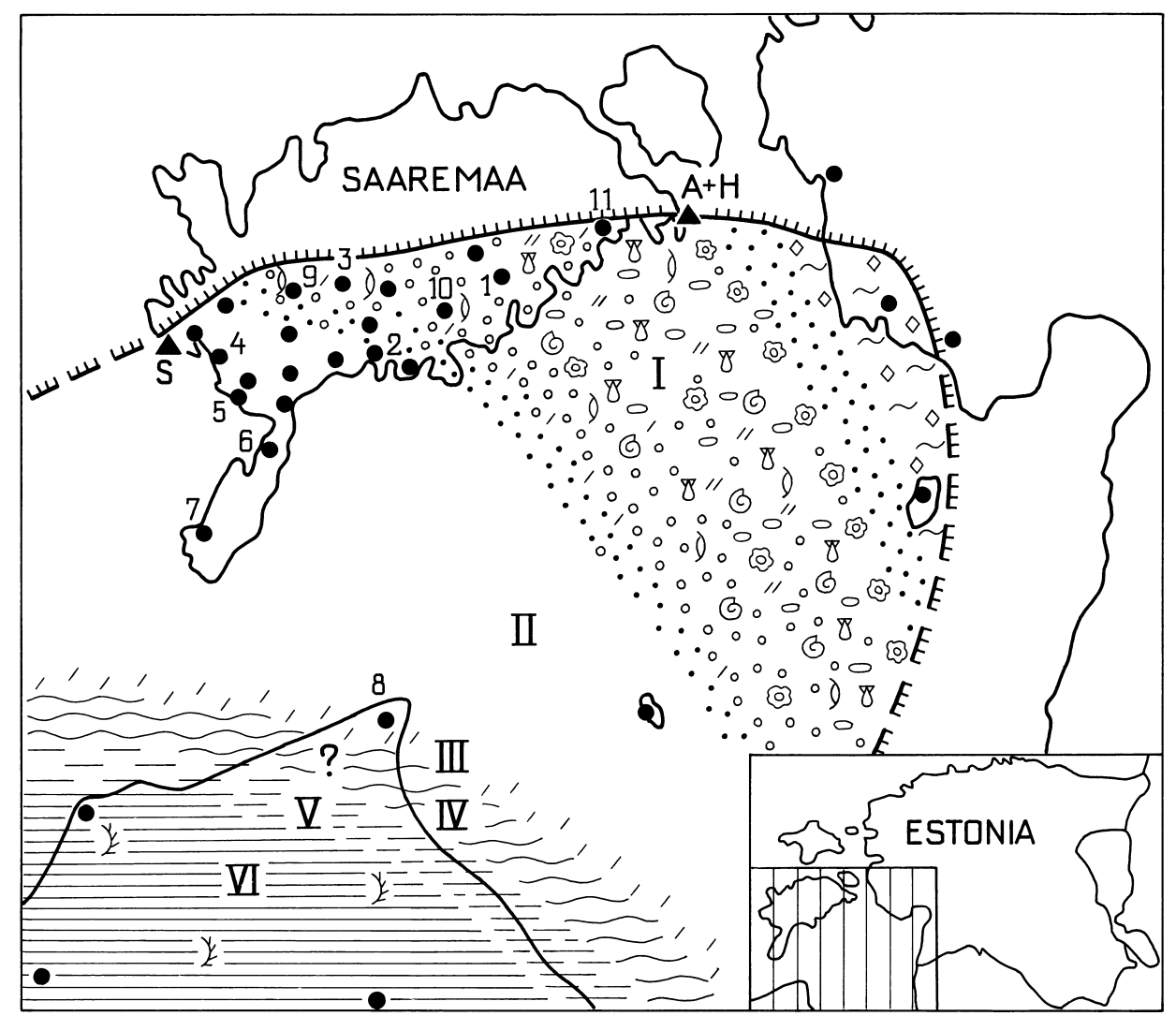

Fig. 2. Location of outcrops (triangles) and boreholes (dots), and facies belts of early Paadla age in southwestern Estonia and northern Latvia. Facies belts: I, onshore shoal; II, non-sedimentation; III, offshore shoal; IV, open shelf; V, slope; VI, basinal. Outcrops and boreholes: S, Soeginina cliff; A+H, Anikaitse and Hülge cliffs; 1, Sakla; 2, Kuressaare; 3, Kaarmise; 4, Kipi; 5, Riksu; 6, Kaugatuma; 7, Ohesaare; 8, Kolka; 9, Sõmera; 10, Tahula; 11, Laimjala. For other legend see Fig. 3.

\section{DESCRIPTION OF SECTIONS}

The end of the Rootsiküla Age was a time of maximum shallowing in the Baltic Silurian Basin, accompanied by notable litho- and biofacies changes. In the shallow-water carbonate sequences, the Rootsiküla and Paadla stages are dominated by cyclically alternating lagoonal dolostones and sparitic calcarenites (often secondarily dolomitized), containing only sporadically impoverished fauna.

In the stratotype Soeginina cliff section (Fig. 3) the following lithologic elementary beds are distinguished (in ascending order, with thicknesses shown):

(1) $0.5+\mathrm{m}-$ microlaminated, silty, argillaceous eurypterid-dolostone with Eurypterus remains, nautiloids, and ostracods (Herrmannina). Large (over $1 \mathrm{~m}$ 


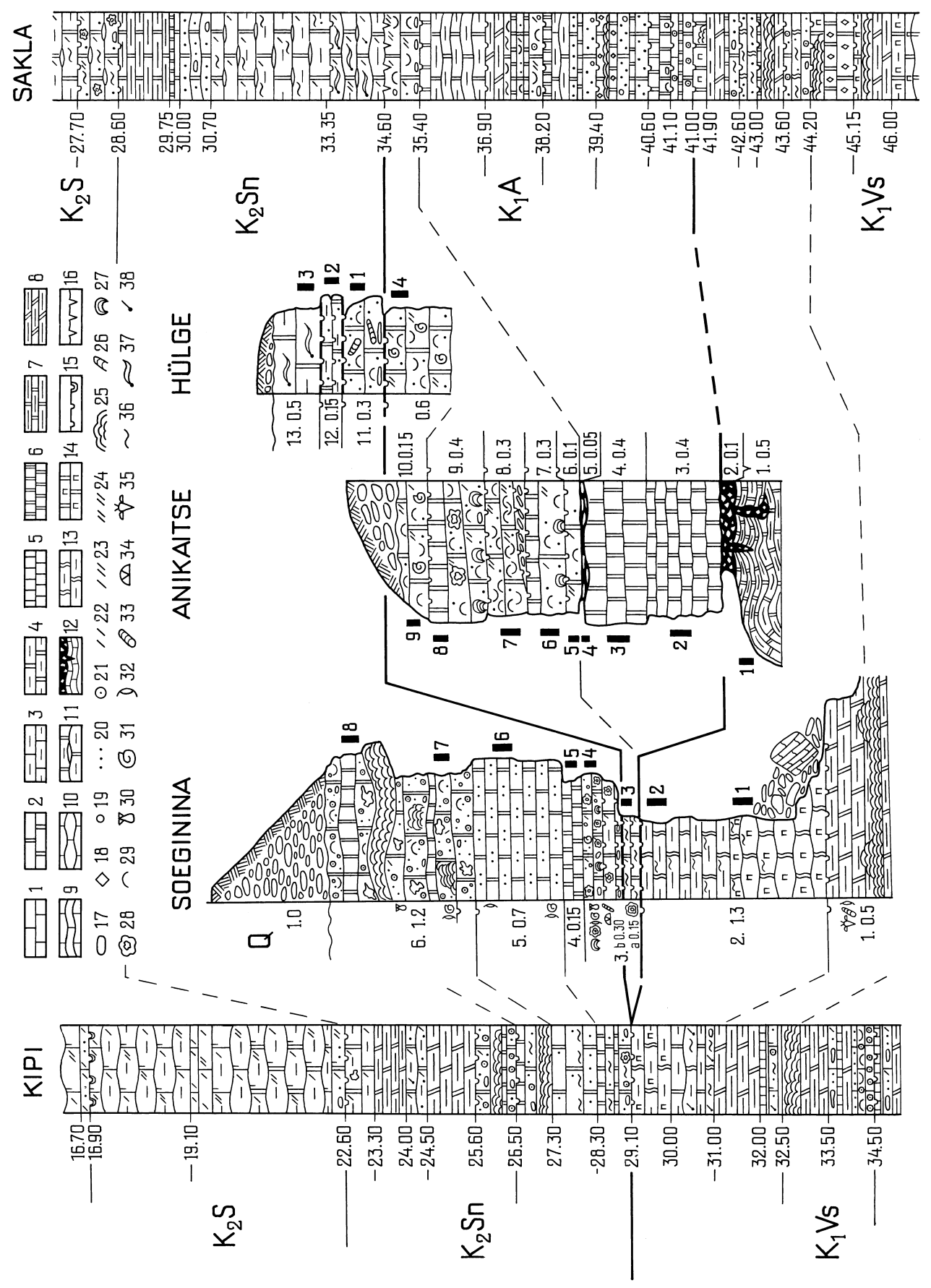


in diameter) Stratifera-type stromatolites occur. The upper boundary is a distinct pyritized discontinuity surface (DS).

(2) $1.3 \mathrm{~m}$ - yellowish-brown, mottled, bioturbated, argillaceous dolostone. The upper boundary is a distinct pyritized DS, the boundary between the higherrank mesocyclites, and the Vesiku Beds of the Rootsiküla Stage and the Soeginina Beds of the Paadla Stage.

(3a) $0.15 \mathrm{~m}$ - brownish-grey, bioturbated, argillaceous dolowackestone with varigrained biodetritus, rare oncolites, some DSs, tongue of the Anikaitse Beds in the lower part.

(3b) $0.30 \mathrm{~m}$ - light brown, varigrained biodetrital dolopackstone to grainstone with oncolites and small stromatolites on the lower distinct smooth DS in the upper part. Nautiloids, bivalves, gastropods, dendroid corals, ostracods, calcareous algae (Solenopora), and bryozoans are present. A lens-like conglomerate interbed $(0-7 \mathrm{~cm})$, with flat pebbles of the underlying dolostone, occurs on the $3 \mathrm{a}$ and $3 \mathrm{~b}$ boundary.

(4) $0.15 \mathrm{~m}$ - light grey, microcrystalline, pure, unfossiliferous dolomudstone.

(5) $0.70 \mathrm{~m}$ - light, brown-grey, fine-grained, skeletal-pelletal dolograinstone with ostracods and gastropods. The upper boundary is a distinct eroded DS.

(6) $1.2 \mathrm{~m}$ - dark brown varigrained pelletal-biodetrital dolofloatstone with oolites, small pebbles of light grey dolomudstone and rounded bivalves, gastropods, ostracods (Herrmannina), intercalated with light grey dolomudstone. The grain size varies considerably. On three levels $0.3-0.4 \mathrm{~m}$ high Stratifera-stromatolites are present. The upper boundary is a distinct erosional bedrock surface covered by coastal pebbles.

The section of this cliff can be correlated bed by bed with the interval of 22.6$33.0 \mathrm{~m}$ of the Kipi borehole (Fig. 3). Conodont studies show that the lower beds 1, 2, and 3a of the Soeginina cliff belong to the Vesiku Beds of the Rootsiküla Stage, while all other beds ( $3 b$ and 4-6) belong to the Paadla Stage (Fig. 3). The same biostratigraphic criteria allow correlation of the Soeginina stratotype section with the lower part of the Sauvere Beds (Paadla Stage) on middle and eastern

Fig. 3. Lithology and correlation of the Wenlock-Ludlow boundary beds in the West and East Saaremaa sections. $\mathrm{K}_{1}$, Rootsiküla Stage; $\mathrm{K}_{2}$, Paadla Stage; Vs, Vesiku Beds; A, Anikaitse Beds; Sn, Soeginina Beds; S, Sauvere Beds. Legend: 1, limestone; 2, dolostone; 3, argillaceous limestone; 4, argillaceous dolostone; 5, micritic limestone (calcareous mudstone); 6, micritic dolostone (dolomitic mudstone); 7, laminated argillaceous dolostone; 8, Eurypterus-dolostone; 9, wave-bedded lime- and dolostone; 10, nodular lime- and dolostone; 11, argillaceous dolostone with domerite (= dolomitic marl); 12, folded microlaminated argillaceous dolostone with mud-cracks and an intraclast interbed on the upper boundary; 13, bioturbated argillaceous dolostone; 14, mottled dolostone; 15, discontinuity surface (burrowed); 16, mud-cracks; 17, pebbles, conglomerate lenses; 18 , intraclasts; 19 , psammite; 20 , pellets; 21 , ooids; 22 , fine-grained skeletal detritus; 23 , unsorted skeletal detritus; 24, coarse skeletal detritus; 25, stromatolites (Stratifera); 26, columnar stromatolites; 27 , encrusting stromatolites; 28 , oncolites; 29, shells; 30, bivalves; 31 , gastropods; 32 , ostracods; 33 , nautilods; 34 , tabulate corals; 35 , eurypterids; 36 , burrows; 37 , pyritized burrows; 38 , pyritized skeletal detritus. Black rectangles denote conodont samples. Depth is in metres. 
Saaremaa (interval $28.6-34.6 \mathrm{~m}$ in the Sakla borehole which traditionally has been assigned to the Sauvere Beds).

The second investigated section, the compound Anikaitse and Hülge cliff section (Fig. 3), consists of 13 elementary beds (in ascending order, with thicknesses shown):

(1) $0.5+m-$ folded, light grey, microlaminated, silty, argillaceous dolostone, with wide (up to $10 \mathrm{~cm}$ ) eroded polygonal mud cracks at the upper boundary.

(2) $0.1 \mathrm{~m}$-dolostone breccia with matrix of dark grey dolomarlstone to -claystone. Breccia fills also the desiccation fissures in the underlying dolostone.

(3) $0.4 \mathrm{~m}$ - light grey dolomudstone, intercalated with thin stylolitized interbeds of dark grey dolomarlstone (domerite).

(4) $0.4 \mathrm{~m}$ - light grey, massive dolomudstone. The upper boundary is wavy and erosional, probably a glaciotectonic displacement plain.

(5) $0.05 \mathrm{~m}$ - dark grey dolomarlstone with rare brecciated particles of the underlying dolomudstone. The upper boundary is a distinct eroded DS.

(6) $0.1 \mathrm{~m}$-yellowish-grey, varigrained, skeletal dolowackestone with rare bivalve remains. The upper boundary is a distinct smooth DS.

(7) $0.3 \mathrm{~m}$ - in the lower part, varigrained, skeletal dolograinstone to packstone with bivalves and small stromatolites above the basal DS; in the upper part $(5-7 \mathrm{~cm})-$ dolomudstone. The upper boundary is a distinct smooth DS. The bed forms an elementary cyclite.

(8) $0.3 \mathrm{~m}$ - dolomitized bivalve coquina with varigrained pelletal-skeletal grainstone matrix. In the lower part occurs a lens-shaped conglomerate interbed $(0-12 \mathrm{~cm})$ with smooth flat pebbles of different dolostones. The upper boundary is a distinct smooth DS.

(9) $0.4 \mathrm{~m}$ - light, yellowish-grey dolostone, similar to bed 7. In the lower part occurs bivalve-gastropod dolograinstone with small stromatolites at the base, in the middle part - skeletal packstone with oncolites, in the upper part $(5-10 \mathrm{~cm})$ dolomudstone.

(10) $0.15+\mathrm{m}$ (in the Hülge cliff more than $0.6 \mathrm{~m}$ ) - yellowish-grey, varigrained, pelletal-skeletal, bivalve-gastropod dolograinstone. The upper boundary is a distinct pyritized smooth DS with erosional marks.

(11) $0.3 \mathrm{~m}$ - brownish-grey, varigrained, skeletal dolograinstone with bivalves, ostracods, and nautiloids. On the lower boundary rare flat pebbles $(5 \mathrm{~cm})$ of dolograinstone and dolomudstone occur. The upper boundary is a distinct smooth DS.

(12) $0.15 \mathrm{~m}$ - dark grey, bioturbated, argillaceous dolowackestone. Distinct pyritized DSs occur in the middle of the bed and at the top.

(13) $0.5+m-$ brownish-grey, bioturbated, argillaceous dolowackestone with large pyritized worm burrows (up to $20 \mathrm{~mm}$ in diameter), specific to the transgressive basal part of the Sauvere Beds.

The upper part of the Anikaitse cliff (beds 6-10) correlates with similar rocks in the Sakla borehole (34.6-35.4 m). Investigations of borehole sections on central Saaremaa have shown that these rocks thin out westwards (Einasto 1975). 


\section{CONODONTS}

The study of conodonts from the boundary beds of the Rootsiküla and Paadla stages shows the prevalence of Ctenognathodus which is present in the specific nearshore fauna, forming the Ctenognathodus association (Aldridge \& Jeppsson 1999). On Saaremaa Island this association occurs in the Viita, Kuusnõmme, Vesiku, Anikaitse, and Soeginina beds of the Rootsiküla and Paadla stages (Fig. 1). The present study shows that in the Anikaitse cliff, which was presumed to represent the Soeginina Beds, this association is accompanied by distinct rather small specimens of Ozarkodina. The overlying Sauvere Beds yield quite a different fauna, containing besides $O$. confluens, O. excavata, and Oulodus siluricus, a robust Ozarkodina roopaensis and Ctenognathodus jeppssoni sp. nov. The zonal conodont species Ozarkodina bohemica is represented by rare specimens, morphologically differing from the holotype.

Samples from the Anikaitse cliff yielded three succeeding taxa, Ctenognathodus sp. S, Ctenognathodus sp. C, and Ctenognathodus sp. P of the genus Ctenognathodus (Fig. 4, Table 1). The genus Ozarkodina is represented by two new species, $O$. anika sp. nov., O. soegina sp. nov., and rare Ozarkodina retroversus and $O$. aff. bicornuta. Samples 4, 8, and 9 revealed a morphologic variety of Ozarkodina aff. bohemica, which has numerous even denticles and a long blade (Pl. III, fig. 11).

The Hülge cliff is situated $1.5 \mathrm{~km}$ north of the Anikaitse cliff. Its lower layers are of the same lithology as the uppermost layers in the Anikaitse section (Fig. 3). This is proved also by findings of such conodonts as Ctenognathodus sp. P, Ozarkodina soegina sp. nov., and $O$. aff. bohemica in sample 4 (Fig. 4, Table 1). From sample 1 upwards a different conodont fauna appears, containing Ozarkodina confluens, O. roopaensis, and elements of the genus Panderodus. Some specimens of "Ligonodina excavata excavata" Jeppsson 1972 occur in sample 3. All these are characteristic of the Sauvere Beds of the Paadla Stage (Viira 1982a, 1999).

Two quite different conodont faunas have been identified from the Soeginina cliff section (Table 2). The lower part of the cliff (three lower samples) yielded representatives of Ctenognathodus sp. S, Ozarkodina wimani, and $O$. aff. bohemica (Fig. 5). Some specimens of Ozarkodina aff. bicornuta, with a big posterior denticle and fused denticles above the basal cavity, were found in samples 2 and 3. From sample 4 upwards, typical species of the Sauvere Beds, such as O. confluens and O. excavata, occur together with a species of the open nomenclature, Ctenognathodus sp. P.

On the grounds of the conodont ranges, four different faunas can be distinguished:

1. In the three lower samples from the Soeginina cliff, Ozarkodina aff. bohemica, O. aff. bicornuta, and O. wimani are common. Ctenognathodus is represented by Ctenognathodus sp. S, which is regarded as a direct successor to C. murchisoni.

2. A fauna with Ctenognathodus sp. S is found in the lower part of the Anikaitse section (samples 1-3). 


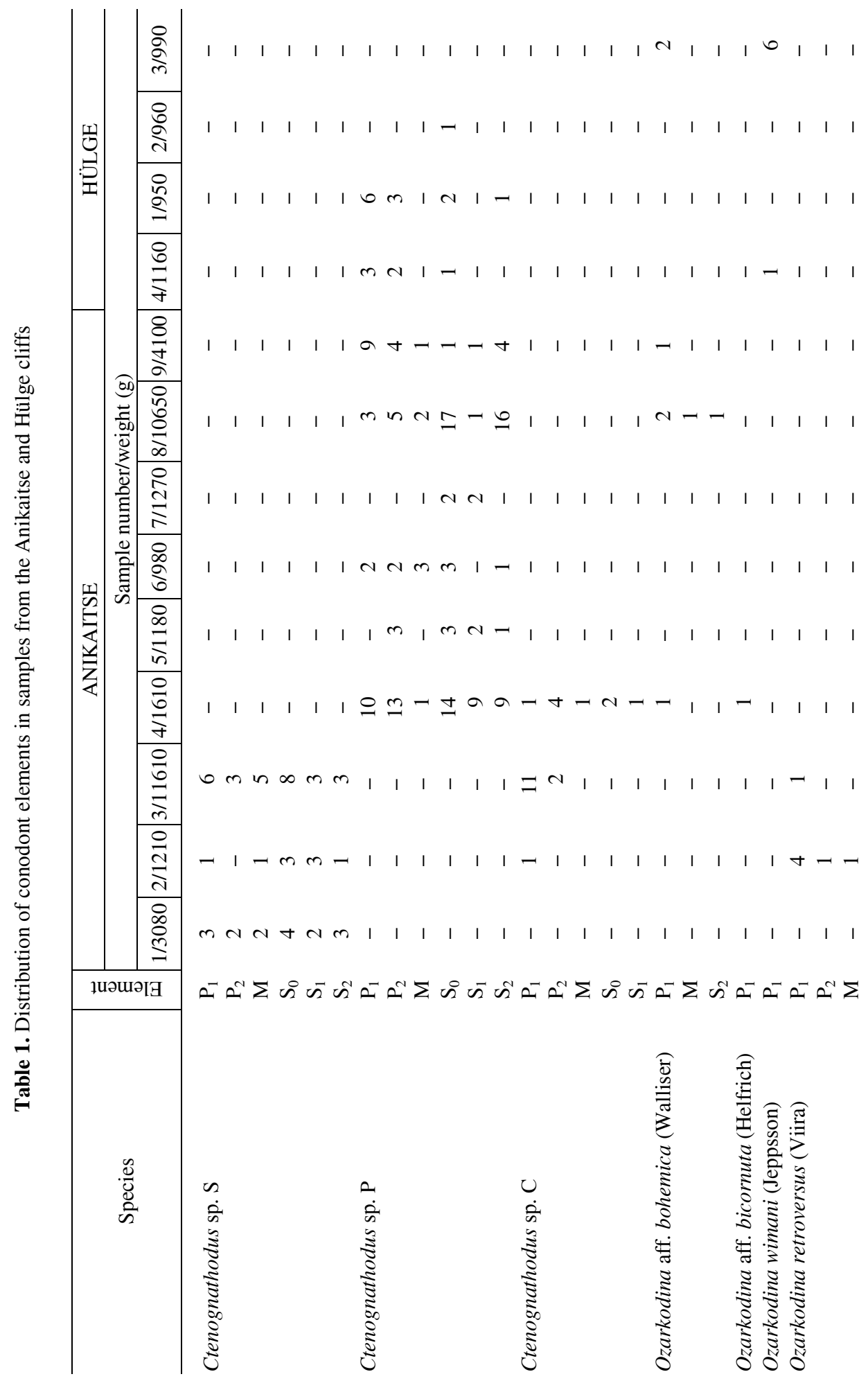




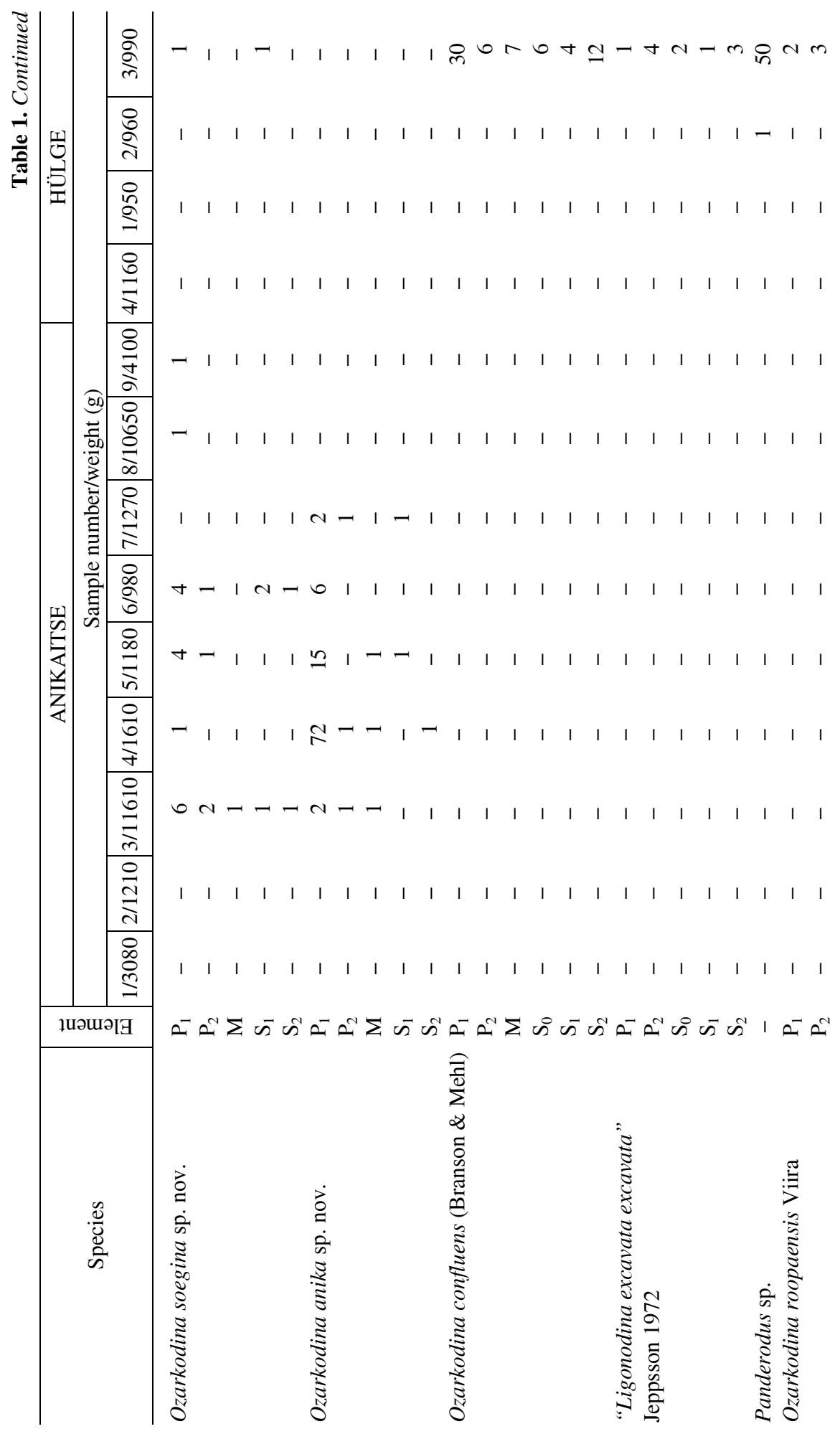




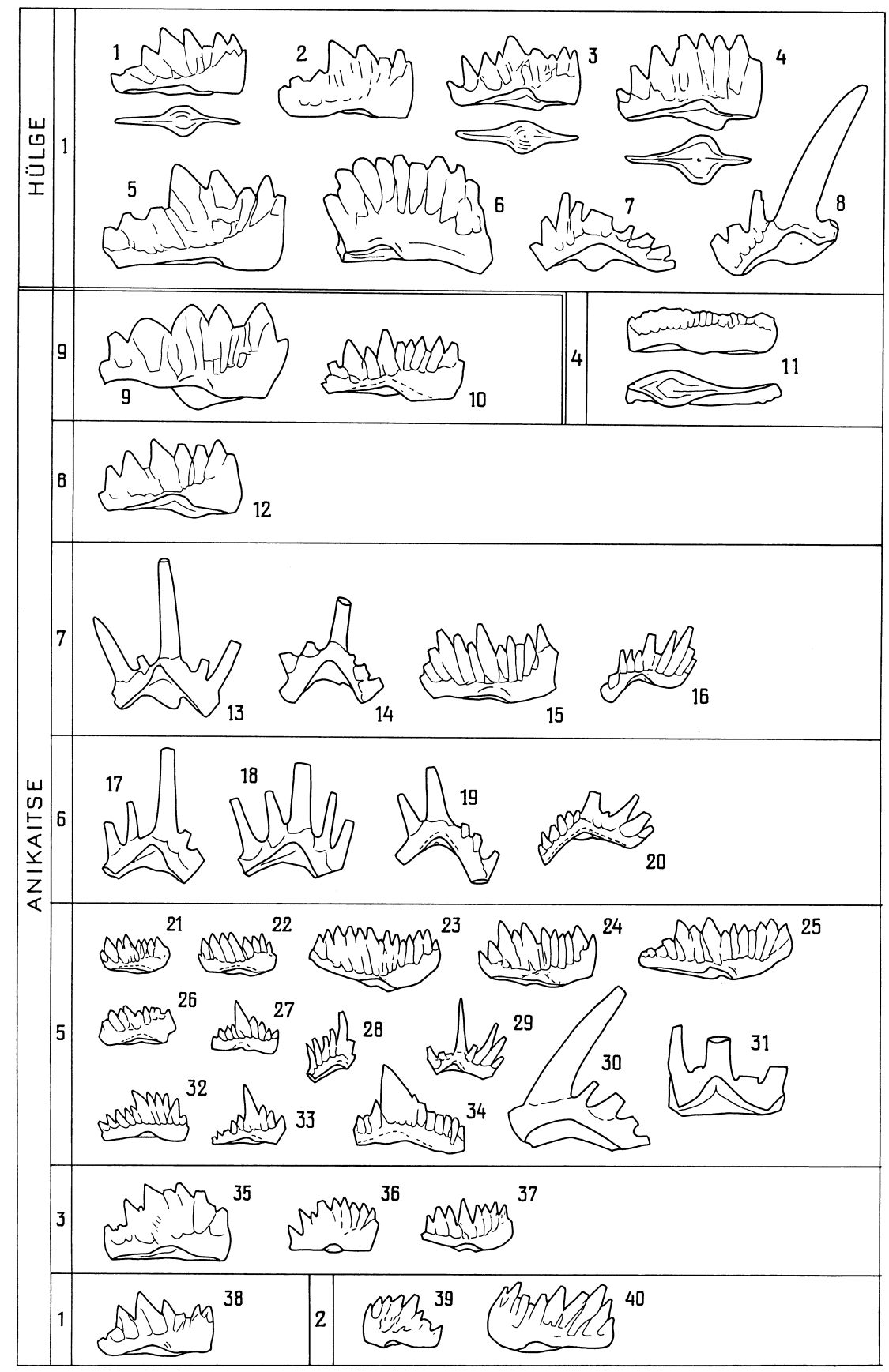

Fig. 4. Selected conodont specimens in samples 1-3, 5-9 from the Anikaitse section and samples 1, 4 from the Hülge section. 1-5, 7-9, 12-14, 17-19, 30, 31, Ctenognathodus sp. P; 6, Ctenognathodus sp. ?C; 10, 20, Ozarkodina soegina sp. nov.; 38, Ctenognathodus sp. S; 11, Ozarkodina aff. bohemica; 15, 16, 21-29, 32, 33, Ozarkodina anika sp. nov.; 34, Ozarkodina sp.; 35, 36, 39, Ctenognathodus sp. C; 37, Ozarkodina wimani; 40, Ozarkodina retroversus. 
Table 2. Distribution of conodont elements in samples from the Soeginina cliff

\begin{tabular}{|c|c|c|c|c|c|c|c|c|c|}
\hline \multirow[b]{2}{*}{ Species } & \multirow[b]{2}{*}{$\begin{array}{l}\vec{\Xi} \\
\vec{\Xi} \\
\frac{\vec{d}}{\mid I}\end{array}$} & \multicolumn{8}{|c|}{ Sample number/weight (g) } \\
\hline & & $\begin{array}{c}1 / \\
2835\end{array}$ & $\begin{array}{c}2 / \\
4150\end{array}$ & $\begin{array}{c}3 / \\
5330\end{array}$ & $\begin{array}{c}4 / \\
5550\end{array}$ & $\begin{array}{c}5 / \\
4300\end{array}$ & $\begin{array}{c}6 / \\
4150\end{array}$ & $\begin{array}{c}7 / \\
4450\end{array}$ & $\begin{array}{c}8 / \\
5150\end{array}$ \\
\hline \multirow[t]{6}{*}{ Ctenognathodus sp. S } & $\mathrm{P}_{1}$ & 8 & 4 & 50 & - & - & - & - & - \\
\hline & $\mathrm{P}_{2}$ & 3 & 4 & 19 & - & - & - & - & - \\
\hline & M & 2 & 2 & 9 & - & - & - & - & - \\
\hline & $\mathrm{S}_{0}$ & 5 & 5 & 29 & - & - & - & - & - \\
\hline & $\mathrm{S}_{1}$ & 9 & 6 & 20 & - & - & - & - & - \\
\hline & $\mathrm{S}_{2}$ & 5 & 14 & 23 & - & - & - & - & - \\
\hline \multirow[t]{6}{*}{ Ctenognathodus sp. $\mathrm{P}$} & $\mathrm{P}_{1}$ & - & - & - & 1 & 3 & 2 & 1 & 4 \\
\hline & $\mathrm{P}_{2}$ & - & - & - & 2 & 2 & 1 & 1 & 2 \\
\hline & M & - & - & - & - & - & 1 & - & 1 \\
\hline & $\mathrm{S}_{0}$ & - & - & - & 1 & 1 & - & - & 2 \\
\hline & $\mathrm{S}_{1}$ & - & - & - & - & 2 & - & - & - \\
\hline & $\mathrm{S}_{2}$ & - & - & - & - & - & - & - & 1 \\
\hline \multirow{4}{*}{$\begin{array}{l}\text { Ozarkodina aff. bohemica } \\
\text { (Walliser) }\end{array}$} & $\mathrm{P}_{1}$ & 6 & 8 & 14 & 1 & - & - & - & - \\
\hline & $\mathrm{P}_{2}$ & 4 & 4 & 4 & - & - & - & - & - \\
\hline & $\mathrm{S}_{1}$ & - & - & 2 & - & - & - & - & - \\
\hline & $\mathrm{S}_{2}$ & - & - & 3 & - & - & - & - & - \\
\hline $\begin{array}{l}\text { Ozarkodina aff. bicornuta } \\
\text { (Helfrich) }\end{array}$ & $\mathrm{P}_{1}$ & - & 1 & 2 & - & - & - & - & - \\
\hline Ozarkodina wimani Jeppsson & $\mathrm{P}_{1}$ & - & - & - & - & - & - & - & - \\
\hline Ozarkodina soegina $\mathrm{sp}$. nov. & $\mathrm{P}_{1}$ & - & - & 4 & 2 & - & 1 & - & - \\
\hline \multirow{6}{*}{$\begin{array}{l}\text { Oulodus siluricus } \\
\text { (Branson \& Mehl) }\end{array}$} & $\mathrm{P}_{1}$ & - & - & - & 2 & - & - & - & - \\
\hline & $\mathrm{P}_{2}$ & - & - & - & 3 & 1 & - & - & - \\
\hline & M & - & - & - & 4 & - & - & - & - \\
\hline & $\mathrm{S}_{0}$ & - & - & - & 3 & - & - & - & 1 \\
\hline & $\mathrm{S}_{1}$ & - & - & - & 2 & - & - & - & - \\
\hline & $\mathrm{S}_{2}$ & - & - & - & 5 & - & - & - & 1 \\
\hline \multirow{6}{*}{$\begin{array}{l}\text { Ozarkodina confluens } \\
\text { (Branson \& Mehl) }\end{array}$} & $\mathrm{P}_{1}$ & - & - & - & 20 & 5 & 14 & - & 2 \\
\hline & $\mathrm{P}_{2}$ & - & - & - & 3 & 1 & 1 & - & - \\
\hline & M & - & - & - & 4 & - & 2 & - & - \\
\hline & $\mathrm{S}_{0}$ & - & - & - & 1 & - & & - & - \\
\hline & $\mathrm{S}_{1}$ & - & - & - & - & - & 2 & - & - \\
\hline & $\mathrm{S}_{2}$ & - & - & - & - & - & 1 & - & - \\
\hline \multirow{6}{*}{$\begin{array}{l}\text { Ozarkodina excavata } \\
\text { (Branson \& Mehl) }\end{array}$} & $\mathrm{P}_{1}$ & - & - & - & 3 & 1 & - & - & - \\
\hline & $\mathrm{P}_{2}$ & - & - & - & 8 & 2 & 2 & - & - \\
\hline & M & - & - & - & 3 & - & 1 & 1 & - \\
\hline & $\mathrm{S}_{0}$ & - & - & - & 5 & - & - & - & - \\
\hline & $\mathrm{S}_{1}$ & - & - & - & 2 & - & 1 & - & - \\
\hline & $\mathrm{S}_{2}$ & - & - & - & 7 & - & 2 & - & - \\
\hline Ozarkodina roopaensis Viira & $\mathrm{P}_{1}$ & - & - & - & 2 & 2 & - & - & - \\
\hline
\end{tabular}




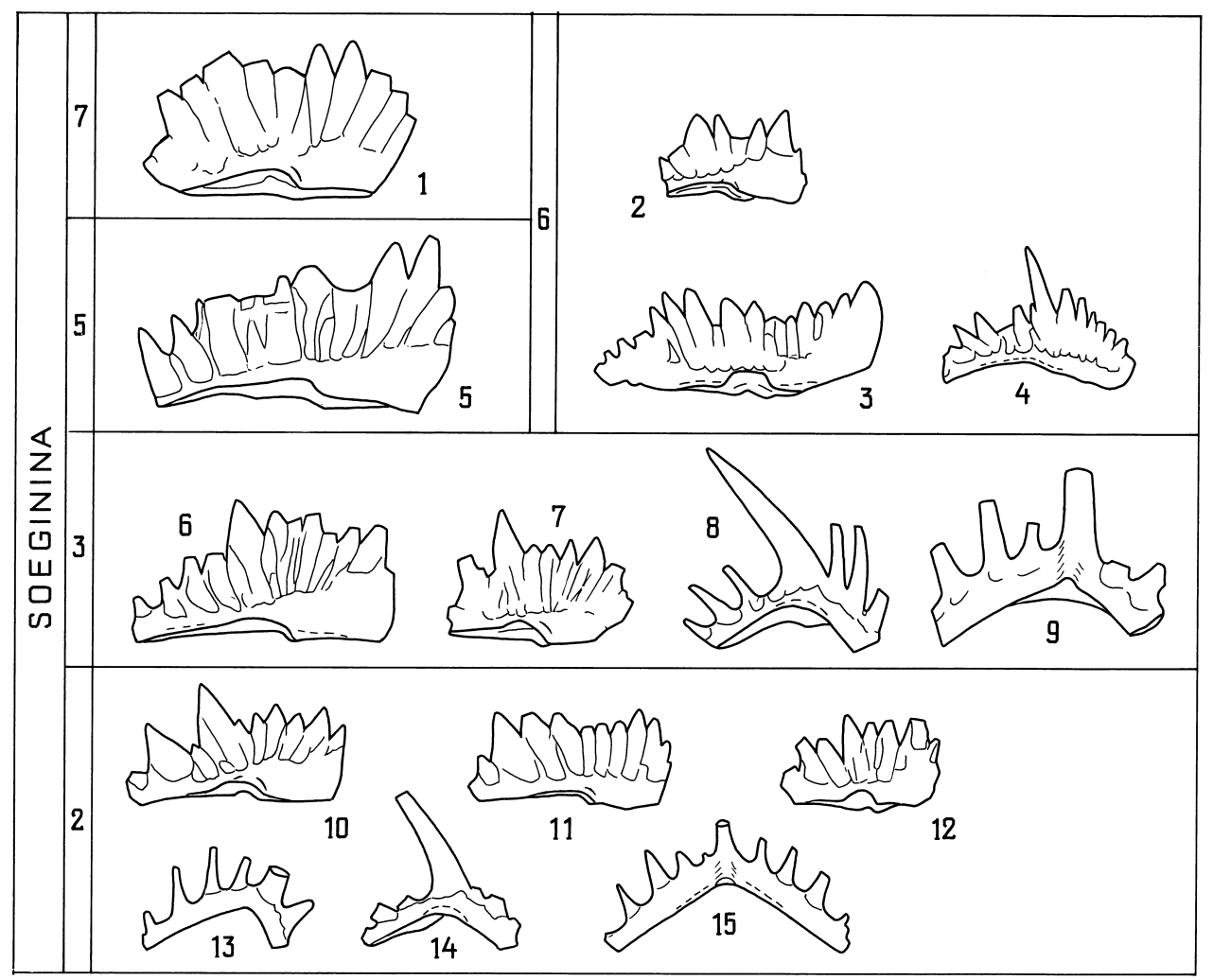

Fig. 5. Selected conodont specimens in samples 2, 3, 5-7 from the Soeginina section. 1, Ctenognathodus sp. ?C; 2, 5-15, Ctenognathodus sp. S; 3, 4, Ozarkodina confluens.

3. Some change of fauna took place in sample 3 and upwards, with the appearance of several new species: Ozarkodina anika sp. nov., O. soegina sp. nov., and Ctenognathodus sp. P. This fauna is found also in sample 4 of the Hülge cliff.

4. The species typical of the Paadla Formation - Ozarkodina confluens, O. excavata, and Oulodus siluricus - are present in the Soeginina (samples 4-8) and Hülge (samples 1-3) cliffs.

Faunas 2 and 3 are lacking in samples from the Soeginina cliff. That level is probably missing in this section.

The upper Wenlock conodonts have earlier been investigated from borehole sections of Saaremaa (Viira 1982b). The present study shows that Ctenognathodus specimens from the upper part of the Vesiku Beds and the Soeginina Beds, identified earlier in borehole sections (Kaarmise, at $25.2 \mathrm{~m}$; Kipi, at $35.4 \mathrm{~m}$; ?Kuressaare, at $46.9 \mathrm{~m}$ ) as C. murchisoni (Viira 1982b, fig. 5.4), actually belong to Ctenognathodus sp. S. This species has been identified also in the Kaarmise (18.5 and $23.9 \mathrm{~m})$, Laimjala (13.8 m), Kuressaare (45.2-45.6 m), and Sõmera 
$(17.4 \mathrm{~m})$ sections. The range of Ctenognathodus sp. P into the Sauvere Beds is confirmed by its findings in the Sakla (at 25.1-34.7 m), Kaarmise (4.5 m), and Laimjala $(13.8 \mathrm{~m})$ boreholes. Ctenognathodus sp. $\mathrm{C}$ has not been found in borehole sections. Ctenognathodus jeppssoni sp. nov has been identified from the following borehole sections: Sakla (23.9-25.6 m), Paadla (5.6-6.75 m), Sõmera (2.1 m), Riksu (27.9 m), Kaugatuma (61.6 and $65.0 \mathrm{~m})$, and Kolka (298.5 m). In several sections, Ozarkodina roopaensis is found lower than C. jeppssoni sp. nov.: at $33.7 \mathrm{~m}$ in Sakla, $11.55 \mathrm{~m}$ in Paadla, 2.9-7.8 $\mathrm{m}$ in Sõmera, and 30.3-39.1 m in Riksu.

The distribution of Ctenognathodus specimens in boreholes shows that one more morphotype, Ctenognathodus sp. A, is present below the typical C. murchisoni range. This type is identified at $49.25 \mathrm{~m}$ in Sakla, $41.15 \mathrm{~m}$ in Paadla, and $49.0 \mathrm{~m}$ in Kaarmise, from the Viita Beds of the Rootsiküla Stage.

\section{MORPHOLOGY OF THE CTENOGNATHODUS $\mathrm{P}_{1}$ ELEMENT}

The conodont succession on Saaremaa Island demonstrates general morphologic changes within the taxa of the genus Ctenognathodus. The studied sections contain a significant part of the range of this genus, which allows us to follow the morphologic changes of the $\mathrm{P}_{1}$ element through the Wenlock-Ludlow boundary beds (Fig. 6). The morphologic trend is expressed in denticles changing from even-sized, through different-sized, to discrete posterior denticles. The earliest species is C.murchisoni in the Kuusnõmme and Vesiku beds of the Rootsiküla Stage (10 and 11 in Fig. 6). Probably it has an ancestor, Ctenognathodus sp. A with a high anterior blade and slowly lowering posterior blade, occurring in the Viita Beds of the Sakla drillcore (13 and 14 in Fig. 6). C. murchisoni has an almost rectangular outline in lateral view and denticles of even height. Morphologically closest to the neotype of C. murchisoni (Gross 1954, pl. 1, fig. 9) is specimen 11 in Fig. 6. Numerous C.murchisoni specimens from the Vesiku outcrop (Viira 1982b, figs. 5.4 and 5.6) show several types of variability, some extremities of which gave rise to Ctenognathodus sp. S and Ctenognathodus sp. C. Specimen 12 in Fig. 6 is an extreme morphotype from the C. murchisoni level, and probably the ancestor of Ctenognathodus sp. C. The morphologic type Ctenognathodus sp. S has wider and higher denticles in the posterior part of the blade (8 and 9 in Fig. 6). Rare specimens of this type are present among numerous specimens of the Pa element of C. murchisoni in the Vesiku locality (Viira 1982b, 5 in fig. 5.6). Ctenognathodus sp. $\mathrm{S}$ is found from the uppermost Vesiku Beds and in the Anikaitse Beds. The subsequent taxon in the lineage is Ctenognathodus sp. C with a short blade and arched denticle line, known only from the Anikaitse Beds (6 and 7 in Fig. 6). Ctenognathodus sp. P is common in the Anikaitse, Soeginina, and Sauvere beds (3-5 in Fig. 6). It has wide anterior denticles, a big cusp and small posterior denticles on the low blade. The two specimens illustrated in Fig. 6, numbered 1 and 2, are $C$. jeppssoni sp. nov. from the Sauvere Beds, which 


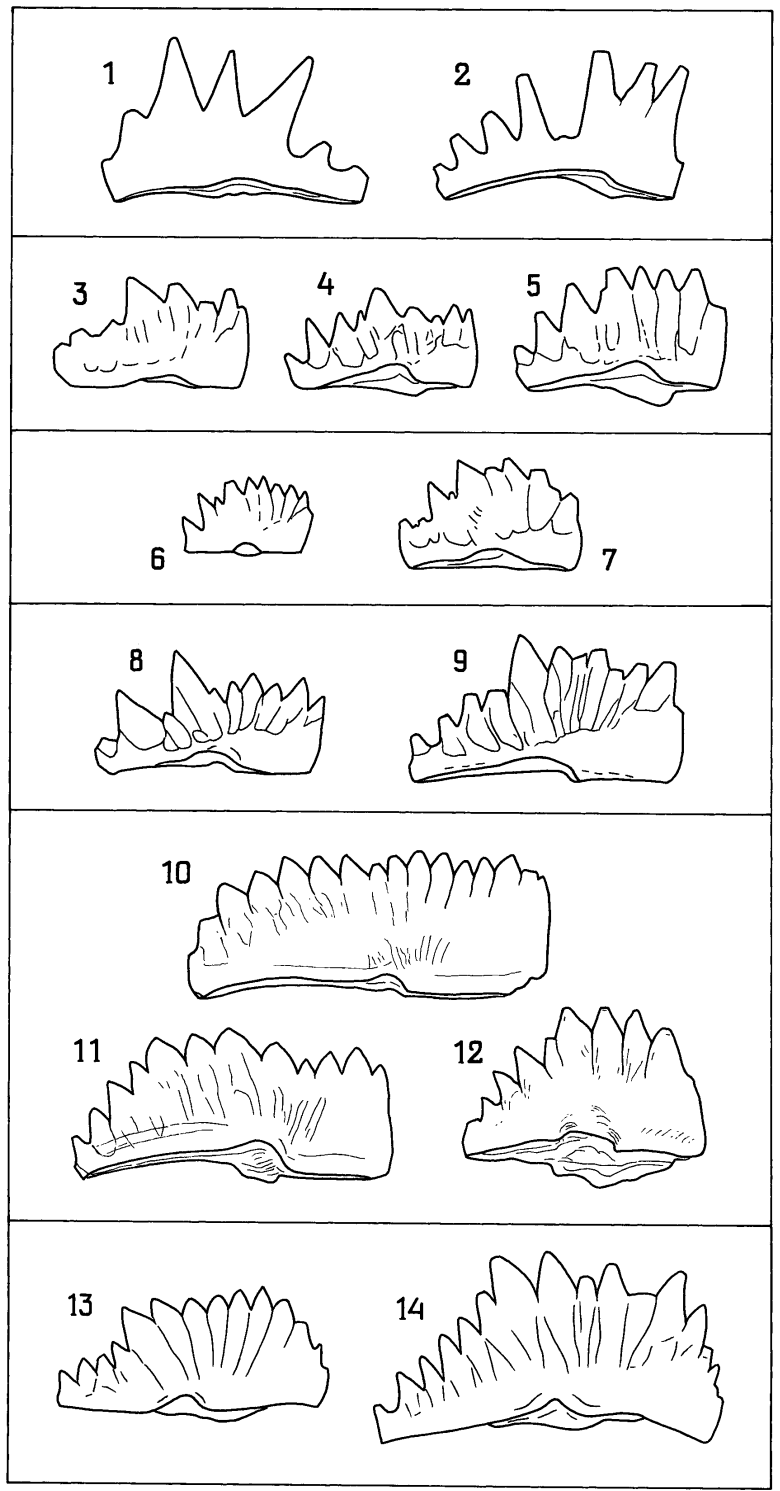

Fig. 6. Element morphology of Ctenognathodus taxa in the Wenlock-Ludlow transition of Saaremaa. 1, 2, Ctenognathodus jeppssoni sp. nov., Sauvere Beds; 3-5, Ctenognathodus sp. P, Anikaitse, Soeginina, and Sauvere beds; 6, 7, Ctenognathodus sp. C, Anikaitse Beds; 8, 9, Ctenognathodus sp. S, uppermost Vesiku and Soeginina beds; 10, 11, 12, Ctenognathodus murchisoni, Kuusnõmme and Vesiku beds; 13, 14, Ctenognathodus sp. A., Viita and Kuusnõmme beds.

probably do not belong to the $C$. murchisoni group. C. jeppssoni sp. nov. has a low blade, big anterior denticles, and low discrete posterior denticles, and is closer to Ctenognathodus n. sp. I n. ssp. G from Gotland (Strömberg 1997).

\section{COMPARISON WITH OTHER AREAS}

As the conodont fauna from the studied sections is very specific, comparison is now possible only in the limits of the Baltic Silurian Basin (Jeppsson et al. 1994). A comprehensive study of the genus Ctenognathodus of Gotland has been performed 
by C. Strömberg on the basis of L. Jeppsson's abundant material (Strömberg 1997). At the present time this manuscript is being prepared for publication. The summary below is based on that study. On Gotland, the genus Ctenognathodus ranges from the Wenlock Högklint Beds to the Ludlow Hemse Beds where seven informal taxa are distinguished. The species Ctenognathodus $\mathrm{n}$. $\mathrm{sp}$. L is synonymous with C. jeppssoni sp. nov. from the Sauvere Beds. The type locality Djaupvuksudden for C. jeppssoni sp. nov. is known as the Hemse Beds, unit "older c". On Gotland, C. murchisoni is found mainly in the Klinteberg Beds ("units a + b"). On Saaremaa, C. murchisoni occurs in the Kuusnõmme and Vesiku beds. C. murchisoni specimens from Gotland are roughly similar to Ctenognathodus specimens from the Viita and Kuusnõmme beds of Saaremaa, which are identified as Ctenognathodus sp. A. The Gotland taxa Ctenognathodus n. sp. D and Ctenognathodus n. sp. E were found in the Hemse Beds, units "older $b+c$ " and "younger a". The last two taxa are in general outline comparable to Ctenognathodus sp. C and Ctenognathodus sp. P from the Anikaitse Beds of Saaremaa. If this is the case, then the Soeginina Beds may be correlated with the lower Hemse Beds (Strömberg 1997).

The conodont fauna of the Wenlock-Ludlow transition of Saaremaa is to some degree comparable also with the fauna from the Wills Creek and Mifflintown formations of the Central Appalachian Mountains, eastern USA (Helfrich 1975). Helfrich's plates show elements of Ozarkodina, mainly O. bicornuta and O. tillmani, which are comparable to elements of this study.

\section{CONCLUSIONS}

Bed-by-bed correlation confirms the stratigraphic conclusions based on conodont studies. It enables us to correlate the stratotype Soeginina section and other sections of the Soeginins Beds on western Saaremaa with the lower part of the Soeginina Beds on eastern Saaremaa (Fig. 3). The dolomitic oncolite and shelly limestones with specific conodont fauna on the Anikaitse and Hülge cliffs (beds 6-10) are traditionally considered as the Soeginina Beds. Actually these limestones thin out towards the base of the Soeginina Beds, not towards the top as it was supposed earlier. The lithologic differences of the Soeginina Beds in former sense, on western, central, and eastern Saaremaa, were explained earlier by facies changes (e.g. Einasto 1970, 1975; Nestor 1997). However, it was difficult to understand why the thickness of these beds was almost equal in different sections, whereas the thickness of the overlying Sauvere Beds was quite variable. Present studies of conodonts enable us to explain lithologic variations as temporal differences between the sections of western and eastern Saaremaa. The distribution of conodont fauna allows of the following conclusions: (1) molluscrich oncolitic, shelly limestones and underlying dolomudstones on the Anikaitse and Hülge cliffs (beds 1-10) are older than lithologically similar beds (3b-6) in the Soeginina stratotype section; (2) the Soeginina Beds on the Soeginina cliff belong to the Paadla Stage, whereas beds 3-10 on the Anikaitse and Hülge cliffs are tentatively assigned to the Rootsiküla Stage. Following this interpretation, we 
propose a new name for these youngest beds of the Rootsiküla Stage on eastern Saaremaa. A suitable name would be the Anikaitse Beds, after the outcrop where these layers are best exposed. In complete thickness the Anikaitse Beds occur in the Sakla drill core in the interval of 34.6-41.6 m, that is, at the level of the Soeginina Beds in former sense.

\title{
SYSTEMATIC PALAEONTOLOGY
}

\author{
Class CONODONTA Eichenberg, 1930 sensu Clark, 1981 \\ Order OZARKODINIDA Dzik, 1976 \\ Family KOCKELELLIDAE Klapper, 1981 \\ Genus Ctenognathodus Fay, 1959
}

Type species. Ctenognathus (= Ctenognathodus) murchisoni Pander, 1856.

Emended diagnosis. Genus with apparatus, comprising two $\mathrm{P}_{1}$, one $\mathrm{M}$, and three $S$ elements. $P_{1}$ blade-like with closely spaced denticles, other five elements with discrete denticles on processes. Basal cavity low, narrow along processes and wider below cusp.

Comparison. $\mathrm{P}_{1}$ element of Ctenognathodus is similar to the analogous element of Ozarkodina, but other elements resemble those of Oulodus. Some similarity may be noticed with Kockelella, particularly if taking into consideration $\mathrm{P}_{1}$ element of Ctenognathodus jeppssoni sp. nov.

Discussion. Pander (1856) named, described, and figured the spathognathodontan $\mathrm{P}_{1}$ element as Ctenognathus (= Ctenognathodus) murchisoni from Rootsikülle (= Rootsiküla) and Sandel (= Sandla) localities of Saaremaa Island. Branson \& Mehl (1933) included this species in synonymy with Spathodus primus (=Ozarkodina confluens). Gross (1954) established that the type species of C. murchisoni has quite distinctive chracters and therefore Ctenognathodus is an independent genus. The reconstruction of the Ctenognathodus apparatus is based on the topotypical material from the thelodont-rich layer of the Vesiku Beds of Saaremaa (Viira 1982b). The conodont fauna of this lagoonal limestone consists almost entirely of a single species, C. murchisoni, and is a good example of "shallow-water conodont specialists" (Aldridge \& Jeppsson 1984). The discovery of the natural assemblage of Ctenognathodus sp. from the Eramosa Member of southern Ontario, Canada, is important for the apparatus architecture of this genus (von Bitter et al. 2002).

Ctenognathodus jeppssoni sp. nov.

Plate I, figures $1-6,8,11,12$

1972 Ligonodina confluens n. ssp. 1; Jeppsson, p. 60, pl. 2, figs. 12-16.

1997 Ctenognathodus n. sp. L (Jeppsson, 1992); Strömberg, p. 45, pl. 1, figs. 1-7; text-fig. 15. 
Holotype. Pa element, LO 4437, Jeppsson 1972, pl. 2, fig. 12.

Type locality. Grogarnshuvud 2, Gotland, Sweden.

Type horizon. Hemse Beds, Ludlow.

Derivation of name. After Lennart Jeppsson who first described and illustrated this taxon.

Material. Sauvere quarry; $15 \mathrm{P}_{1}$ (some fragmentary), $2 \mathrm{P}_{2}, 4 \mathrm{M}, 7 \mathrm{~S}_{0}, 1 \mathrm{~S}_{1}$, and $2 \mathrm{~S}_{2}$ elements.

Diagnosis. Elements of the apparatus robust, with few, wide discrete, peg-like denticles on processes. Carminate $\mathrm{P}_{1}$ element with two kinds of denticles, high triangular denticles in the anterior part and discrete denticles in the posterior part. $\mathrm{P}_{2}, \mathrm{M}$, and $\mathrm{S}$ elements with discrete denticles. All elements quite large.

Description (addition to Jeppsson 1972). $\mathrm{P}_{1}$ element: anterior process moderately high with 3-5 high, triangular denticles; posterior part of base low and with 2-4 discrete equal-size denticles. Dextral and sinistral $\mathrm{P}_{1}$ elements are not mirror images, they differ in the character of anterior denticles and lengths of anterior and posterior parts of blade. Base of anterior part rather high and thickened, posterior part process-like. Basal cavity shallow, posterior groove a bit wider than anterior, both tapering distally. Cavity lobes small. White matter irregularly defines denticles or roots of denticles.

$\mathrm{P}_{2}$ element: posterior process short, with 2-3 discrete, rather high denticles, anterior process directed aborally and inwards, with 3-4 discrete denticles, a little higher than those of the posterior process, cusp very high. Denticles oval in crosssection. Basal cavity rather widely open beneath cusp, grooves moderately wide, especially posterior one. White matter mostly in denticles.

M element: processes of unequal length, with longer anterior process. Cusp prominent, denticles stout, widely spaced. Basal cavity rather deep, passing slowly over into posterior moderately wide groove. Base of cusp thickened on inside.

S elements: with prominent cusp, discrete long denticles; basal cavity deeper and wider below cusp, grooves narrow. White matter only in denticles.

Occurrence. Sauvere Beds of Saaremaa, Hemse Beds of Gotland.

\section{Ctenognathodus sp. A}

Figure $6(13,14)$

Description. Pa element: anterior part of blade high, posterior part gradually lowering. Anterior denticles quite numerous, decreasing in height anteriorly, posterior denticles of equal size, lower at posterior end; 1-2 central denticles above basal cavity usually wider and higher.

Occurrence. Few specimens from the Viita and Kuusnõmme beds in the Sakla (49.25 m), Paadla (41.15 m), and Kaarmise (49.0 m) borehole sections. 


\section{Ctenognathodus sp. C}

Plate II, figures 9-12; Figure $4(35,36,39)$

Description. $\mathrm{P}_{1}$ element: small; blade short and high. In lateral view denticle row arched, with highest denticles above basal cavity. Posterior denticles slightly inclined, height decreasing posteriorly. Basal cavity with rather wide rounded lobes, situated centrally. White matter defines irregularly denticle roots.

$\mathrm{P}_{2}, \mathrm{M}$, and $\mathrm{S}$ elements similar to those of $C$. murchisoni. The closest taxon in Gotland may be Ctenognathodus n. sp. D Strömberg 1997.

Occurrence. Anikaitse cliff of Saaremaa, Anikaitse Beds.

\section{Ctenognathodus sp. $\mathrm{P}$}

Figure $4(1-5,7-9,12-14,17-19,30,31)$

Description. $\mathrm{P}_{1}$ element: blade rather high in anterior and central parts, and low posterior part. 2-3 central denticles a little higher than anterior ones. Most denticles rather wide. Basal cavity with small lobes and narrow posterior groove, situated centrally. White matter defines irregurarly denticle roots.

$\mathrm{P}_{2}, \mathrm{M}$, and $\mathrm{S}$ elements are similar to those of C. murchisoni. This taxon is in general similar to Ctenognathodus n. sp. E Strömberg, 1997.

Occurrence. Anikaitse, Soeginina, and Sauvere beds of Saaremaa.

\section{Ctenognathodus sp. S}

Plate I, figures 7, 10; Figure 4 (38); Figure 5 (6-12)

Description. $\mathrm{P}_{1}$ element: anterior part of blade high, cusp big and wide, next to cusp posterior denticle is also big and high, slightly inclined posteriorly. Posterior part of blade low, with 1-3 small denticles. Basal cavity with small lobes and narrow posterior groove, situated centrally. White matter defines rather regularly denticle roots.

$\mathrm{P}_{2}, \mathrm{M}$, and $\mathrm{S}$ elements are similar to those of $C$. murchisoni.

Occurrence. Upper Vesiku and Anikaitse beds of Saaremaa.

\section{Explanation of Plate I}

Figs. 1-6, 8, 11, 12. Ctenognathodus jeppssoni sp. nov. 1, $\mathrm{P}_{1}$ element No. 371-1; 2, $\mathrm{P}_{1}$ element No. 371-2; 3, $\mathrm{S}_{0}$ element No. 371-3; 4, $\mathrm{S}_{1}$ element No. 371-4; 5, $\mathrm{P}_{2}$ element No. 371-5; 6, $\mathrm{S}_{2}$ element No. 371-6; 8, $\mathrm{P}_{1}$ element No. 371-7; 11, $\mathrm{P}_{1}$ element No. 371-8; 12, M element No. 371-9. 1-3, 5, 6, Sauvere quarry, sample 9; 4, 11, 12, Kärla outcrop, sample 1; 8, Tõri outcrop, sample 1.

Figs. 7, 10. Ctenognathodus sp. S. 7, $\mathrm{P}_{1}$ element No. 371-10; 10, $\mathrm{S}_{1}$ element No. 371-11. Anikaitse cliff, sample 3 .

Fig. 9. “Ligonodina excavata excavata” Jeppsson 1972. ? $\mathrm{P}_{2}$ element No. 371-12. Figs. 1, 2, 3, 6, 10, 11, $12 \times 45$; figs. 7, $9 \times 65$; figs. $5,8 \times 90$. 
PLATE I

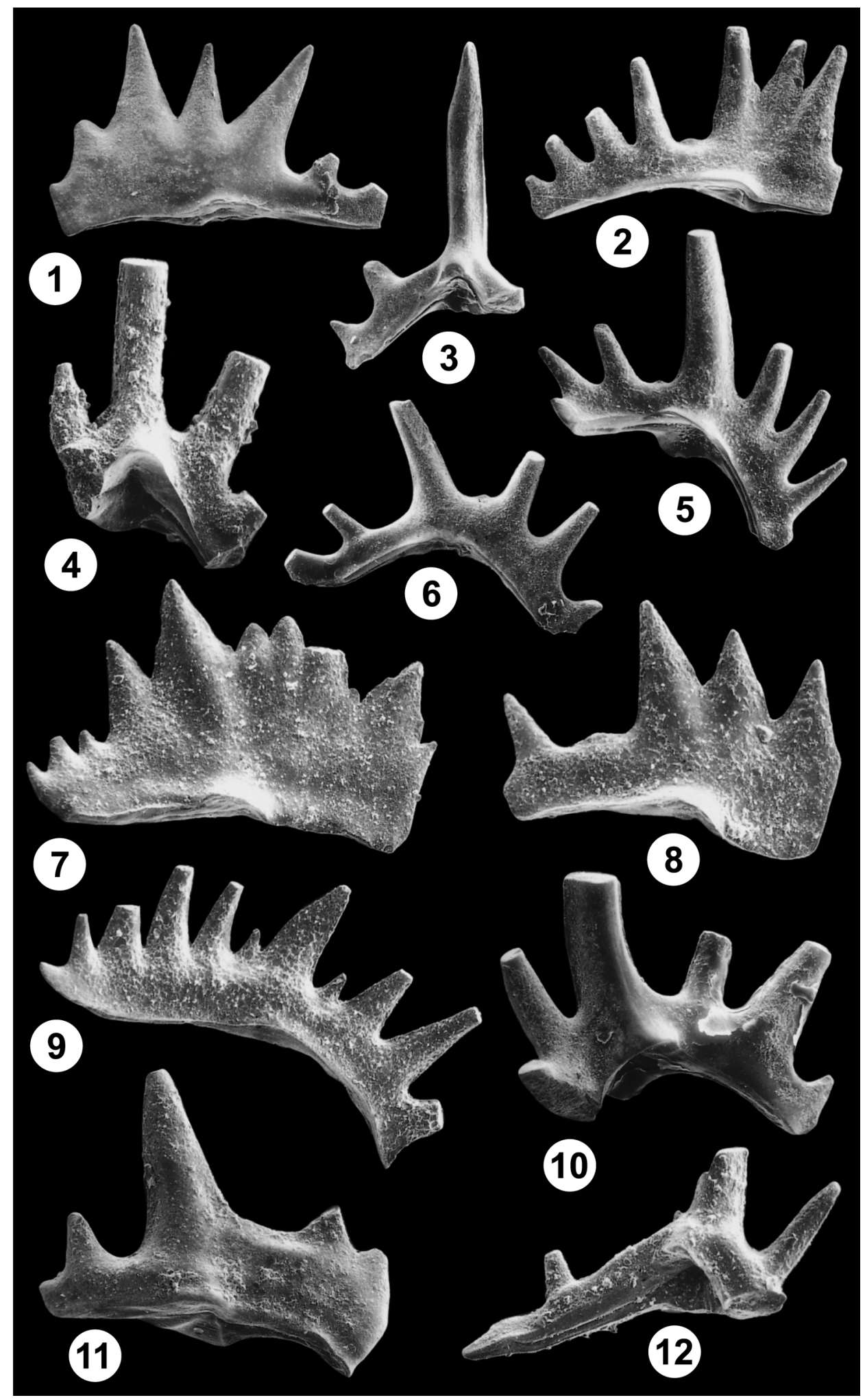




\section{Family SPATHOGNATHODONTIDAE Hass, 1959 \\ Genus Ozarkodina (Branson \& Mehl, 1933)}

Ozarkodina anika sp. nov.

Plate II, figures 1-6; Figure 4 (21-29, 32, 33)

Holotype. Pa element, No. 371-13, Pl. II, fig. 5.

Type locality. Anikaitse cliff, sample 4.

Type horizon. Anikaitse Beds.

Derivation of name. After Anikaitse cliff, Saaremaa Island.

Material. Anikaitse cliff; $97 \mathrm{P}_{1}, 3 \mathrm{P}_{2}, 3 \mathrm{M}, 2 \mathrm{~S}_{1}$, and $1 \mathrm{~S}_{2}$ elements.

Diagnosis. $\mathrm{P}_{1}$ element with smaller and narrower denticles in the anterior half and bigger denticles in the posterior half of the blade. Basal cavity small, with rounded lobes. Denticles of all elements closely spaced and needle-like.

Description. $\mathrm{P}_{1}$ element: carminate, blade rather high, with $10-13$ needle-like denticles that are bigger in the posterior end, the biggest being situated above the basal cavity. Denticles slightly inclined posteriorly, especially in the posterior part, usually finely striated, with lens-like cross-section. Basal cavity circular, situated centrally, groove extends only to posterior tip of blade. White matter defines denticle roots except below the distalmost denticles, and reaches basal cavity in central part of blade.

$\mathrm{P}_{2}$ element: short blade, cusp rather high and wide. Denticles small, slightly higher in anterior part. Basal cavity small. White matter clearly defines denticles.

$\mathrm{M}$ element: anterior process rather long, with high needle-fused denticles; posterior process short, with 2-3 small denticles near the high cusp.

S elements resemble analogous elements of Ozarkodina remscheidensis. Processes with needle-fused denticles.

Occurrence. Anikaitse Beds, rarely in the Sauvere Beds of Saaremaa.

\section{Explanation of Plate II}

Figs. 1-6. Ozarkodina anika sp. nov. $\mathrm{P}_{1}$ elements Nos. 371-13-371-18. 1-5, Anikaitse cliff, sample 6; 6, Karala outcrop, sample 2.

Figs. 7, 8. Ozarkodina wimani Jeppsson. $\mathrm{P}_{1}$ elements Nos. 371-19 and 371-20. Soeginina cliff, sample 3 .

Figs. 9-12. Ctenognathodus sp. C. $\mathrm{P}_{1}$ elements Nos. 371-21-371-24. Anikaitse cliff, sample 3.

Figs. 1, 3, 5, 8, 9, 10, $12 \times 100$; figs. 2, 4, $11 \times 120$; figs. $6,7 \times 60$. 
PLATE II

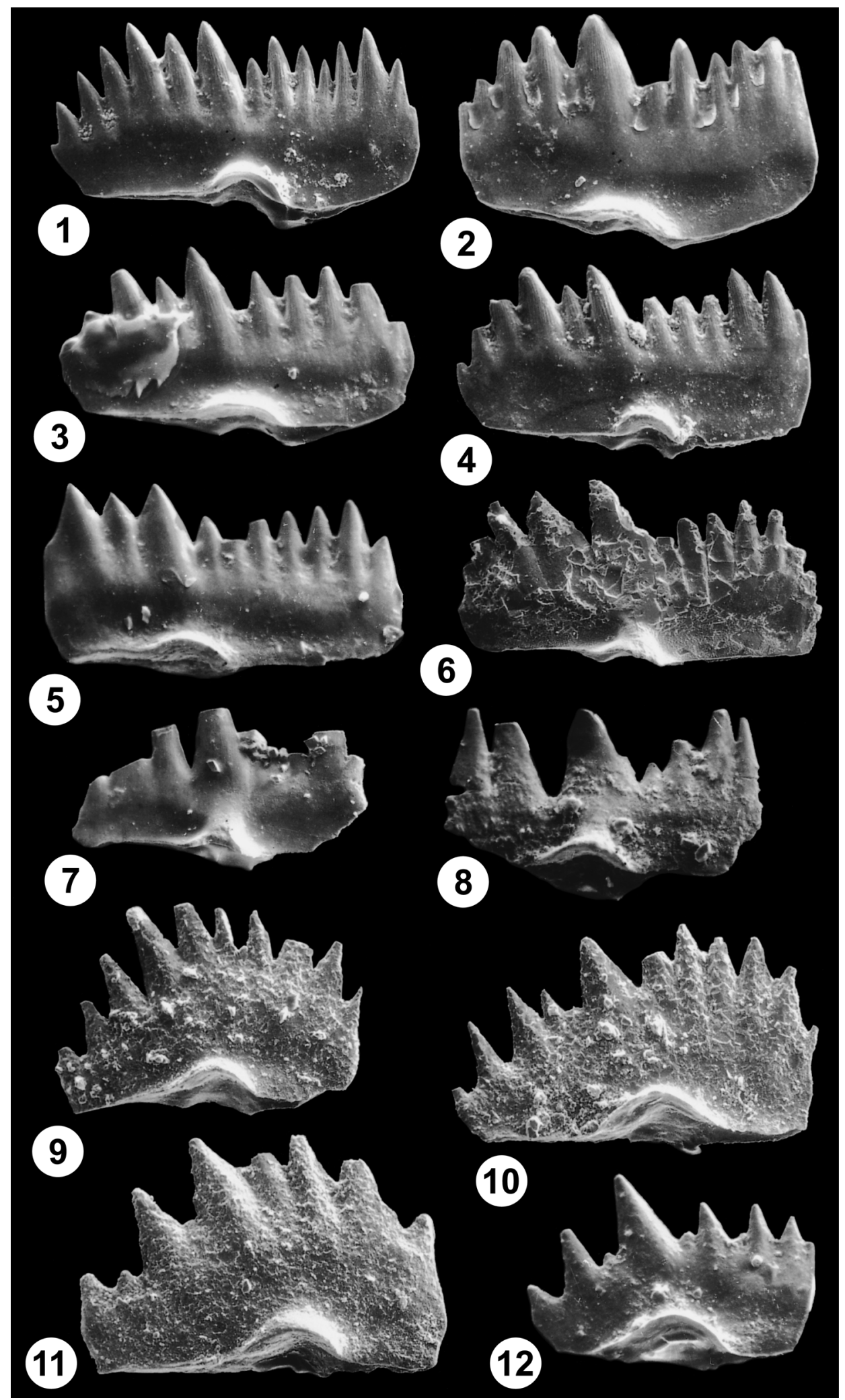


Ozarkodina soegina sp. nov.

Plate III, figures 1-6

Holotype. Pa element, No. 371-27, Pl. III, fig. 3.

Type locality. Soeginina cliff, Saaremaa Island.

Type horizon. Soeginina Beds, Wenlock-Ludlow transition.

Derivation of name. After Soeginina cliff.

Material. Soeginina and Anikaitse cliffs; $25 \mathrm{P}_{1}, 4 \mathrm{P}_{2}, 1 \mathrm{M}, 4 \mathrm{~S}_{1}$, and $2 \mathrm{~S}_{2}$ elements.

Diagnosis. $\mathrm{P}_{1}$ element with long blade and stout fused denticles. Characteristic are 2-3 higher denticles in posterior part of blade.

Description. $\mathrm{P}_{1}$ element: carminate; blade long, with 11-15 triangular to stout denticles that are biggest in posterior third of blade. Cusp may be quite big and 2-3 anteriormost denticles a little higher than others in anterior row. Crosssection of denticles oval. Basal cavity situated centrally, basal lobes rather wide, asymmetrical (Pl. III, fig. 2). Posterior groove moderately wider than anterior groove, both shallow and tapering to extremities. White matter only in roots of central denticles, reaching basal cavity pit. Basal body extends over basal lobes as in $O$. confluens group.

$\mathrm{P}_{2}$ element: blade low and rather long. Anterior denticles closely spaced and higher than triangular posterior denticles. Basal cavity small.

$\mathrm{Pb}, \mathrm{M}$, and $\mathrm{S}$ elements resemble those of Ozarkodina confluens.

Remarks. The $\mathrm{P}_{1}$ element of this species resembles that of Ozarkodina confluens, but bigger denticles occur not in the anterior but in the posterior part of the blade.

Occurrence. Anikaitse and Soeginina beds of Saaremaa.

\section{Explanation of Plate III}

Figs. 1-6. Ozarkodina soegina sp. nov. $\mathrm{P}_{1}$ elements Nos. 371-25-371-30. 1-3, 6, Soeginina cliff: 1, 3, sample 4; 2, sample 3; 6, sample 6; 4, 5, Anikaitse cliff: 4, sample 4; 5, sample 6.

Figs. 7, 9. Ozarkodina confluens (Branson \& Mehl). $\mathrm{P}_{1}$ elements Nos. 371-31 and 371-32. Soeginina cliff: 7, sample 4; 9 , sample 6.

Fig. 8. Ozarkodina sp. $\mathrm{P}_{1}$ element No. 371-33. Soeginina cliff, sample 3.

Figs. 10-13. Ozarkodina aff. bohemica (Walliser). $\mathrm{P}_{1}$ elements No. 371-34, No. Cn 1465, No. 371-35. Soeginina cliff: 10 , sample 4; 12 , sample 2; 13, sample 1; Anikaitse cliff: 11, sample 8.

Fig. 14. Ozarkodina aff. bicornuta. $\mathrm{P}_{1}$ element No. Cn 1467, Anikaitse cliff, sample 4.

Figs. 1, 3, 4, 7, $9 \times 40$; figs. 5, 6, 10, $13 \times 65$; figs. 2, 8, 11, $12 \times 100$; fig. $14 \times 120$. 
PLATE III

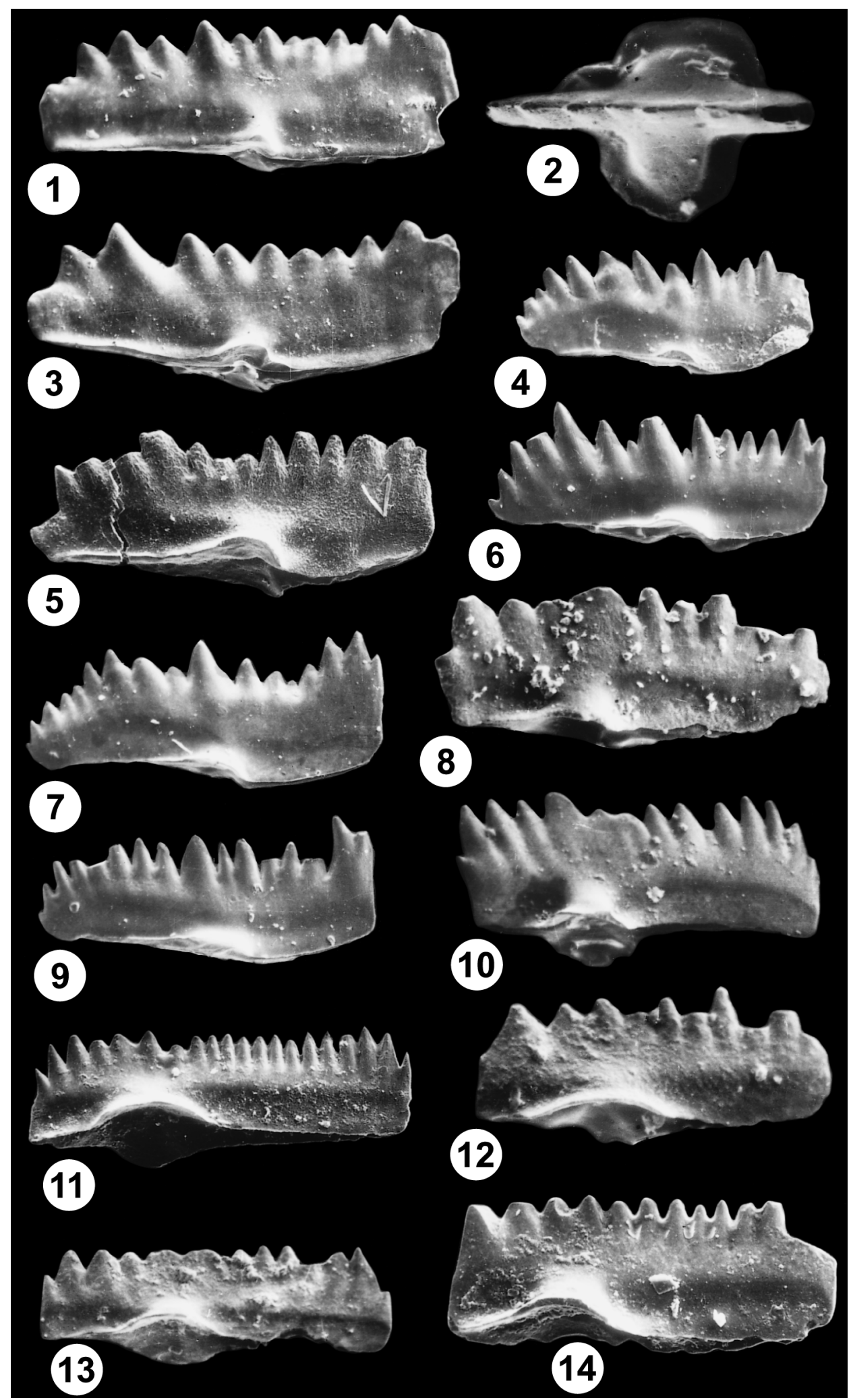




\section{Ozarkodina aff. bohemica (Walliser)}

Plate III, figures 10, 11, 12, 13; Figure 4 (11)

Remarks. This taxon from the Anikaitse, Hülge, and Soeginina cliffs comprises morphologically different specimens. Some specimens that have a quite long blade with numerous small denticles (Pl. III, fig. 11; 11 in Fig. 4) are similar to Ozarkodina bohemica longa Jeppsson (Calner \& Jeppsson 2003). Other specimens are of medium length, moderately wide, usually without fused denticles and centrally-posteriorly situated basal cavity. These specimens may belong to the group of Ozarkodina b. bohemica $\beta$ morph (Viira \& Aldridge 1998).

\section{Ozarkodina aff. bicornuta (Helfrich)}

Plate III, figure 14

Remarks. Three samples from the Soeginina and Anikaitse cliffs yielded a few specimens of Ozarkodina Pa element, somewhat similar to O. bicornuta described by Helfrich (1975) from the Mifflintown Formation of Wills Mountain Anticline, Central Appalachian, USA. The difference is that our specimens have smaller extreme anterior and posterior denticles of the blade than Appalachian specimens.

\section{ACKNOWLEDGEMENTS}

The authors thank D. Kaljo and the referees H. Nestor and M. Purnell for the critical reading of the manuscript. The first author is grateful to L. Jeppsson for fruitful discussions and free access to his collections. The authors thank K. Ronk and G. Baranov for technical help. Financial support for this research was provided by the Estonian Science Foundation (grants Nos. 4160 and 5088).

\section{REFERENCES}

Aaloe, A. O. 1963. On the stratigraphic position and conditions of sedimentation containing Tremataspis mammilata. ENSV TA Geol. Inst. Uurimused, 13, 83-90 (in Russian).

Aldridge, R. J. \& Jeppsson, L. 1984. Ecological specialists among Silurian conodonts. Spec. Pap. Palaeontol., 32, 141-149.

Aldridge, R. J. \& Jeppsson, L. 1999. Wenlock-Pridoli recurrent conodont associations. In Paleocommunities - a Case Study From the Silurian and Lower Devonian (Boucot, A. J. \& Lawson, J. D., eds.), pp. 37-41. Cambridge University Press.

Branson, E. B. \& Mehl, M. G. 1933. Conodonts from the Bainbridge (Silurian) of Missouri. Missouri Univ. Studies, 8, 39-52.

Calner, M. \& Jeppsson, L. 2003. Carbonate platform evolution and conodont stratigraphy during the middle Silurian Mulde Event, Gotland, Sweden. Geol. Mag., 140, 173-203.

Einasto, R. 1962. The correlation of the most important sections of the Kaarma stage. ENSV TA Geol. Inst. Uurimused, 10, 221-236 (in Russian). 
Einasto, R. 1970. The Rootsiküla Stage. In Silur Éstonii (Kaljo, D. L., ed.), pp. 264-276. Valgus, Tallinn (in Russian).

Einasto, R. 1975. The stratigraphical position of Kaarma dolomites in the Estonian Ludlovian sequence. ENSV TA Toim. Keemia Geol., 24, 75-79 (in Russian).

Einasto, R. 1991. Silur. In Geology and Mineral Resources of Estonia: Excursion Guide (Puura, V., Kalm, V. \& Puura, I., eds.), pp. 7-9. Tallinn.

Einasto, R. 1996. The stratigraphic scheme of the Estonian Ordovician and Silurian against the background of the cyclic evolution. In The Third Baltic Stratigraphical Conference (Meidla, T., Puura, I., Nemliher, J., Raukas, A. \& Saarse, L., eds.), pp. 23-24. Tallinn.

Gailite, L. K., Ulst, R. J. \& Yakovleva, V. I. 1987. Stratotipicheskie razrezy silura Latvii. Zinatne, Riga (in Russian).

Gross, W. 1954. Zur Conodonten-Frage. Senck. leth., 35, 73-85.

Helfrich, C. T. 1975. Silurian conodonts from Wills Mountain Anticline, Virginia, West Virginia, and Maryland. Geol. Soc. Amer. Spec. Pap., 161.

Jaeger, H. 1959. Graptholiten und Stratigraphie des jüngsten Thüringer Silurs. Abh. Deutsch. Akad. Wiss. Berlin, Kl. Chem., Geol. u. Biol., 2.

Jaeger, H. 1976. Das Silur und Unterdevon vom thüringischen Typ in Sardinien und seine regionalgeologische Bedeutung. Nova Acta Leopoldina, 45, 263-299.

Jeppsson, L. 1972. Some Silurian conodont apparatuses and possible conodont dimorphism. Geol. Palaeont., 6, 51-69.

Jeppsson, L., Viira, V. \& Männik, P. 1994. Silurian conodont-based correlations between Gotland (Sweden) and Saaremaa (Estonia). Geol. Mag., 131, 201-218.

Kaljo, D., Kiipli, T. \& Martma, T. 1997. Carbon isotope event markers through the WenlockPridoli sequence at Ohesaare (Estonia) and Priekule (Latvia). Palaeogeogr. Palaeoclimatol. Palaeoecol., 132, 211-223.

Kaljo, D., Kiipli, T. \& Martma, T. 1998. Correlation of carbon isotope events and environmental cyclicity in the East Baltic Silurian. In Silurian Cycles. Linkages of Dynamic Stratigraphy with Atmospheric, Oceanic, and Tectonic Changes (Landing, E. \& Johnson, M. E., eds.). New York State Mus. Bull., 491, 297-312.

Klaamann, E. R. 1970. The Paadla Stage. In Silur Éstonii (Kaljo, D. L., ed.), p. 276. Valgus, Tallinn (in Russian).

Luha, A. 1930. Über ergebnisse stratigraphischer Untersuchungen im Gebiete der Saaremaa (Ösel)Schichten in Eesti (Unterösel und Eurüpterus-Schichten). Acta Univ. Tartu, A 18, 6.

Luha, A. 1933. Eesti. Geoloogiline koostis. In Eesti Entsüklopeedia, Vol. 2. Tartu.

Nestor, H. 1997. Silurian. In Geology an Mineral Resources of Estonia (Raukas, A. \& Teedumäe, A., eds.), pp. 86-106. Estonian Academy Publishers, Tallinn.

Nestor, H, \& Einasto, R. 1997. Ordovician and Silurian carbonate sedimentation basin. In Geology and Mineral Resources of Estonia (Raukas, A. \& Teedumäe, A., eds.), pp. 192-204. Estonian Academy Publishers, Tallinn.

Nestor, V. \& Nestor, H. 1991. Dating of the Wenlock carbonate sequences in Estonia and stratigraphic breaks. Proc. Estonian Acad. Sci. Geol., 40, 50-60.

Pander, C. H. 1856. Monographie der fossilen Fische des silurischen Systems der russischbaltischen Gouvernments. Acad. Wiss. St.-Petersburg, 1-91.

Purnell, M. A., Donoghue, P. C. J. \& Aldridge, R. J. 2000. Orientation and anatomical notation in conodonts. J. Paleontol., 74, 113-122.

Strömberg, C. 1997. The conodont genus Ctenognathodus in the Silurian of Gotland, Sweden. Examenarbete, $\mathrm{Nr}$ 85. Geologiska Institutionen, Lunds Universitet (unpublished).

Viira, V. 1982a. Late Silurian shallow and deep water conodonts of East Baltic. In Ecostratigraphy of the East Baltic Silurian (Kaljo, D. \& Klaamann, E., eds.), pp. 79-88. Valgus, Tallinn.

Viira, V. 1982b. Shallow-water conodont Ctenognathodus murchisoni (Late Wenlock, Estonia). In Communities and Biozones in the Baltic Silurian (Kaljo, D. \& Klaamann, E., eds.), pp. 63-83. Valgus, Tallinn (in Russian). 
Viira, V. 1999. Late Silurian conodont biostratigraphy in the northern East Baltic. In Boll. Soc. Paleont. Italiana, 37, 299-310.

Viira, V. \& Aldridge, R. J. 1998. Upper Wenlock to Lower Př́idolí (Silurian) conodont biostratigraphy of Saaremaa, Estonia, and a correlation with Britain. J. Micropalaeont., 17, 33-50.

von Bitter, P. H., Purnell, M. A., Tetreault, D. K. \& Scott, C. A. 2002. Natural conodont assemblages from the Eramosa Member (Guelph Formation) of southern Ontario, Canada. Strata, série 1, 12, 66 .

\title{
Wenlocki-Ludlow' piirikihid ja konodondid Saaremaal
}

\author{
Viive Viira ja Rein Einasto
}

Saaremaa Wenlocki-Ludlow' piirikihtide konodontide faunas on tähtis osa perekonna Ctenognathodus esindajatel. Anikaitse, Hülge ja Soeginina pangalt pärit kollektsioonid sisaldavad Ctenognathodus'e kolm uut esialgset taksonit ja Ozarkodina kaks uut liiki. Uus liik Ctenognathodus jeppssoni sp. nov. on kirjeldatud Sauvere kihtidest (Ludlow). Konodondid kinnitavad arvamust, et Soeginina kihid on Saaremaa stratotüüpses läbilõikes Ludlow' ladestiku alumine ühik. Varem Soeginina kihtidesse paigutatud Anikaitse panga spetsiifilise konodondifaunaga kihid on arvatud iseseisvaks litostratigraafiliseks üksuseks - Anikaitse kihtideks. 